Tersedia online di: http://ejournal-balitbang.kkp.go.id/index.php/JP
e-mail:jurnalpari@gmail.com
JURNAL PARI
Volume 6 Nomor 2 Desember 2020
p-ISSN: 2502-0730
e-ISSN : 2549-0133

\title{
PENGARUH TINGKAT PENDIDIKAN PENELITI TERHADAP PENGGUNAAN REFERENSI DALAM PENULISAN KARYA ILMIAH
}

\author{
Syarianah \\ Balai Riset Perikanan Budidaya Air Payau dan Penyuluhan Perikanan, Maros \\ Diterima tanggal : 09 September 2020 Diterima setelah perbaikan : 09 Oktober 2020 \\ disetujui terbit : 22 Desember 2020
}

\section{ABSTRAK}

Kajian dilakukan untuk mengetahui pengaruh tingkat pendidikan peneliti terhadap penggunaan referensi dalam penulisan karya tulis ilmiah. Kajian dilakukan terhadap karya tulis peneliti Balai Riset Perikanan Budidaya Air Payau dan Penyuluhan Perikanan yang dipublikaikan melalui Jurnal Riset Akuakultur. Hasil kajian menunjukkan bahwa jumlah karya tulis ilmiah peneliti yang dipublikasikan selama 3 tahun sebanyak 32 artikel terdiri dari pendidikan strata 3 (14 artikel), strata 2 (16 artikel), dan strata 1 (2 artikel). Rata-rata jumlah penggunaan referensi untuk tingkat pendidikan strata 3 sebanyak 31,25 artikel, strata 2 sebanyak 18,00 artikel, dan strata 1 sebanyak 44,5 artikel. Peniliti dengan tingkat pendidikan strata 3 dan 2 lebih sering menggunakan majalah/ jurnal sebagai bahan referensi utama. Sedangkan peneliti dengan tingkat pendidikan strata 1 lebih banyak menggunakan buku/monograf sebagai bahan referensi utama. Peneliti dengan tingkat pendidikan strata 3 lebih banyak menggunakan referensi yang berusia $1 \mathrm{~s} / \mathrm{d} 10$ tahun (195 artikel). Sedangkan pendidikan strata 2 dan 1 lebih banyak menggunakan referensi yang berusia $11 \mathrm{~s} / \mathrm{d}$ 20 tahun (masing-masing 172 dan 30 artikel).

\section{Kata Kunci: Penggunaan Referensi; Karya IImiah; Pengaruh Tingkat Pendidikan}

\begin{abstract}
The study was conducted to examine the effect of the researcher's education level on the use of references in writing scientific papers. The study was conducted on article the of researchers published in the Jurnal Riset Akuakultur. The results of the study showed that the number of scientific papers published by researchers was 32 articles consisting of strata 3 (14 articles), strata 2 (16 articles), and strata 1 (2 articles). The average number of reference uses for strata 3 was 31.25 articles, for strata 2 as many as 18.00 articles, and for strata 1 as many as 44.5 articles. Researchers with a level 3 and 2 education often use magazines / journals as the main reference material. Meanwhile, researchers with a bachelor's level education often use books / monographs as the main reference material. Researchers with a strata 3 education level mostly use references aged 1 to 10 years (195 articles). Meanwhile, for strata 2 and 1 education mostly use references aged 11 to 20 years (172 and 30 articles respectively.
\end{abstract}

\section{Keywords: Reference Use; Scientific Writing; Effect of Education Level}




\section{PENDAHULUAN}

Dewasa ini banyak jurnal ilmiah yang diterbitkan oleh instansi pemerintah maupun swasta. Penerbitan jurnal tersebut dimaksudkan untuk menyebarluaskan hasil-hasil riset dan informasi lain yang berkaitan dengan misi dan visi instansi yang bersangkutan (Martyn S. 2009). Lebih lanjut dikemukanan bahwa Informasi yang dihasilkan diharapkan dapat bermanfaat bagi para ahli dan praktisi yang berkecimpung di bidangnya masing-masing serta untuk menyempurnakan suatu informasi yang belum jelas, sehingga pengguna dapat mengikuti ilmu pengetahuan dan teknologi yang sedang berkembang pada saat itu dan pada masa yang akan datang. Jurnal adalah terbitan berkala yang berbentuk pamflet berseri berisi bahan yang sangat diminati orang saat diterbitkan . Bila dikaitkan dengan kata ilmiah di belakang kata jurnal dapat terbitan berarti berkala yang berbentuk pamflet yang berisi bahan ilmiah yang sangat diminati orang setelah diterbitkan.

Tujuan utama dari karya tulis ilmiah adalah untuk mengkomunikasikan temuan dari penelitian penulis. Hasil temuan mungkin muncul tak berarti, karena semua penelitian ilmiah dibuat berdasarkan hasil pekerjaan para peneliti sebelumnya. Namun demikian sekecil apapun temua harus dituangkan ke dalam kertas untuk menempatkan penemuan baru penulis ke dalam konteks yang tepat. Oleh karena itu, sebuah deskripsi penelitian yang dipublikasikan tepat di lapangan sangat penting untuk kebenaran dan kredibilitas makalah itu (Hasley, MJ. dalam Taylor, D. McD. 2002). Kegiatan penelitian biasanya diawali dengan ide-ide atau gagasan dan konsep-konsep yang dihubungkan satu sama lain melalui hipotesis tentang hubungan yang diharapkan. Ide-ide dan konsep-konsep untuk penelitian dapat bersumber dari gagasan peneliti sendiri dan dapat juga bersumber dari sejumlah kumpulan pengetahuan hasil kerja sebelumnya yang kita kenal juga sebagai literatur atau pustaka (Huda, F.A. 2017).

Dalam penulisan karya ilmiah penelitian, orang akan menggunakan informasi dari sumber lain, dan penting untuk digunakan dalam kutipan teks untuk mengakreditasi peneliti lain. Sebagian besar pengantar dan banyak dari diskusi, melibatkan hasil atas penelitian orang lain, menempatkan proyek penelitian dalam konteks temuan sebelumnya di lapangan. Sangat dapat diterima untuk mengutip karya orang lain dan, pada kenyataannya, sangat penting untuk melakukannya. Kadang-kadang, kita akan menggunakan kutipan langsung dari sumber lain. Kutipan dari literatur atau bahan pustaka ini kemudian kita jadikan sebagai referensi atau landasan teoritis dalam penelitian. Kita harus membuat daftar pustaka atau daftar referensi dari semua sumber yang digunakan, dan kita juga harus menunjukkan dalam teks di mana informasi tersebut berasal. Menurut Martyn S. (2009) referensi adalah bagian penting dari penulisan karya ilmiah penelitian. Pengetahuan umum tidak perlu direferensikan, dan dapat diasumsikan bahwa setiap pembaca cukup berpengetahuan tentang bidang ini.

Sayangnya, referensi makalah ilmiah sering dilakukan kurang tepat. Banyak penulis menganggap referensi sebagai sesuatu yang relatif tidak penting dalam teks utama, namun ketidaktepatan dapat merusak validitasnya. Bagian referensi tidak boleh dianggap sebagai sebuah pekerjaan kecil yang harus dibiarkan sampai saat-saat terakhir.

Referensi yang tidak pantas, tidak akurat, atau format yang salah bukan hanya masalah teknis tetapi mungkin menjadi alasan yang cukup bagi seorang editor untuk mengembalikan kertas itu untuk revisi bahkan sebelum peer review. Beberapa tujuan referensi dikemukakan oleh Asmana, A. (1999) yaitu

1. Memperkuat pernyataan atau argumentasi. Suatu informasi yang disampaikan, baik secara lisan atau tulisan, membutuhkan rujukan untuk memperkuat informasi tersebut. Dengan adanya referensi maka suatu informasi mempunyai landasan dan dasar yang kuat sehingga dapat dianggap sebagai informasi yang dapat dipertanggung-jawabkan.

2. Menghindari plagiarisme. Setiap karya seseorang merupakan hak kekayaan intelektual dari penulis tersebut, ketika seseorang menggunakan informasi dari hasil karya orang lain tersebut, maka ia harus mencantumkan sumber rujukan tulisannya agar tidak dianggap sebagai pelaku plagiat.

3. Bentuk penghargaan karya orang lain. Para penulis atau peneliti telah menghabiskan waktu, pikiran, dan tenaga dalam membuat sebuah karya. Oleh karena itu, sudah sepantasnya pihak yang menggunakan hasil karya mereka menjelaskan dari mana sumber rujukan sebagai bentuk penghargaan.

4. Menambah informasi bagi pembaca. Pencantuman referensi bertujuan juga untuk memberikan informasi lebih dalam kepada pembaca mengenai suatu topik.

Selain itu referensi membantu dalam memvalidasi suatu tulisan, meningkatkan keterbacaan, dan mengarahkan pembaca yang tertarik ke yang lain dan sesuai. Referensi dapat digunakan sebagai otoritas tertinggi untuk mendasarkan argumen. atau, mereka 
dapat menjadi otoritas sementara yang validitasnya bermaksud untuk menantang atau dianggap salah. Di sinilah letak esensi perbandingan dan kontras antara temuan penulis dan orang lain. Konsistensi dengan temuan orang lain dapat membantu validasi temuan penulis dan dapat memberikan dukungan untuk teori yang berkembang. Namun, inkonsistensi dapat menantang teori yang ada dan menunjukkan arah untuk penelitian lebih lanjut.

\section{TUJUAN \& METODOLOGI}

Kajian ini bertujuan untuk :

1. Mengidentikasi jumlah karya tulis ilmiah yang dipublikasikan berdasarkan tingkat pendidikan

2. Menganalisa pengaruh tingkat pendidikan terhadap jumlah, jenis, dan usia referensi yang digunakan dalam penulisan karya ilmiah.
Kajian ini mengidentifikasi jumlah karya tulis ilmiah yang terbit pada jurnal dalam negeri bidang kelautan dan perikanan yang di publikasikan oleh Puslitbang Perikanan Budiaya yang berjudul Jurnal Riset Akuakultur. Sampel yang digunakan adalah semua karya tulis ilmiah peneliti Balai Riset Perikanan Budidaya Air Payau dan Penyuluhan Perikanan (BRPBAPPP) yang diterbitkan selama tiga tahun yaitu tahun 2013 s/d 2015 dengan 10 terbitan yaitu volume 8 (No. 1-3); volume 9 (No. 1-3); dan volume 10 (No. 1-4). Data diperoleh dari data primer dan data sekunder. Data sekunder diperoleh melalui buku-buku dan laporan untuk menunjang informasi yang diperlukan. Analisis data dilakukan terhadap jumlah karya tulis ilmiah, jenis literatur, usia literatur, dan bahasa literatur yang dirujuk. Jenjang pendidikan peneliti diperoleh dari data Kepegawaian BRPBAPPP, Maros, yang dikelompokkan berdasarkan tingkat pendidikan strata 1, strata 2 , dan strata 3 (Tabel 1).

Tabel 1. Jumlah Peneliti BRPBAPPP berdasarkan Tingkat Pendidikan

\begin{tabular}{cccc}
\hline No. & Tingkat Pendidikan & Jumlah (Org) & $\%$ \\
\hline 1 & S1 & 2 & 16 \\
2 & S2 & 26 & 52 \\
3 & S3 & 16 & 32 \\
& Jumlah & 50 & 100 \\
\hline
\end{tabular}

Jenis referensi yang digunakan dikelompokkan menjadi majalah/jurnal ilmiah, buku/monograf, prosiding, skripsi/tesis/disertasi, dan artikel lain (laporan, makalah, brosur, peta, dan informasi dari internet). Analisis data dengan menggunakan rumus Chi Kuadrat (Sugiono 2003) dengan bantuan program Microsoft Excel. Untuk menghitung nilai X2 dan koefisien kontingensi $(\mathrm{C})$ digunakan rumus sebagai berikut:

$$
\begin{aligned}
& r 1\left(O_{i j}-E_{i j}\right)^{2} X^{2} \\
& X 2=\sum \sum----- \text { dan } \mathrm{C}=v-----
\end{aligned}
$$$$
i=1 \mathrm{j}=1 \mathrm{~N}+\mathrm{X}^{2}
$$$$
\text { dimana: }
$$

$X=$ Chi-kuadrat

$\mathrm{O}=$ frekuensi yang diobservasi

$\mathrm{E}=$ frekuensi yang diharapkan

$\mathrm{C}=$ koefisien kontingensi

$\mathrm{N}=$ jumlah sampel

\section{PEMBAHASAN}

Jumlah karya tulis ilmiah yang dipublikasikan pada Jurnal Riset Akuakultur berdasarkan tingkat pendidikan peneliti

Karya tulis ilmiah peneliti BRPBAPPP yang diterbitkan selama tiga tahun (2013 s/d 2015) pada
Jurnal Riset Akuakultur berjumlah 32 artikel yaitu volume 8 (No. 1-3) sebanyak 12 artikel; volume 9 (No. 13) sebanyak 12 artikel; dan volume 10 (No. 1-4) sebanyak 8 artikel. Penulis dikelompokkan berdasakan tingkat pendidikan seperti pada Gambar 1 .

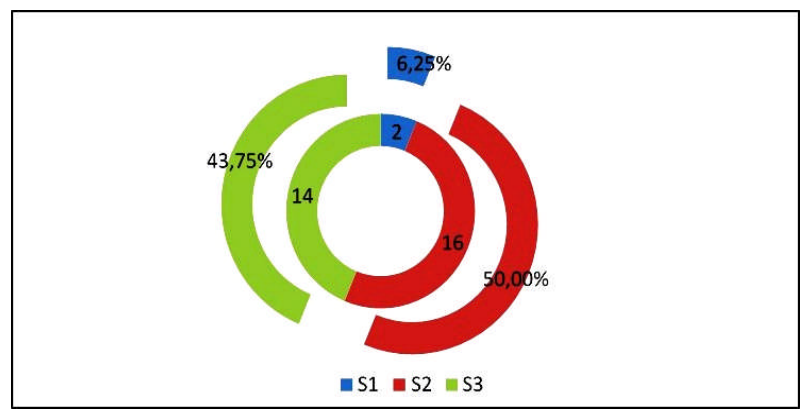

Gambar 1. Jumlah dan persentase karya tulis ilmiah peneliti BRPBAPPP berdasarkan tingkat pendidikan selama tahun (2013 s/d 2015)

Hasil analisis mendapatkan bahwa dalam tiga tahun tingkat pendidikan strata1 hanya menghasilkan 2 karya tulis ilmiah atau sebesar 6,25\% dengan jumlah peneliti sebanyak 2 orang, tingkat pendidikan strata2 menghasilkan 16 karya tulis ilmiah atau sebesar $50,00 \%$ dengan jumlah peneliti sebanyak 16 orang. Sedangkan tingkat pendidikan strata3 menghasilkan 14 karya tulis atau sebesar $43,75 \%$ dengan jumlah peneliti sebanyak 16 orang. Hal tersebut menunjukkan bahwa tingkat pendidikan strata2 menghasilkan artikel tertinggi karena jumlah penelitinya juga banyak. 
Namun apabila dirata-ratakan hanya menghasilkan 0,205 artikel/tahun/peneliti. Sedangkan untuk pendidikan strata3 dengan jumlah karya tulis ilmiah sebanyak 14 arikel dirata-ratakan memperoleh nilai 0,332 artikel/tahun/peneliti, dan untuk tingkat pendidikan strata1 dengan jumlah karya tulis ilmiah 2 artikel jika dirata-ratakan memperoleh nilai 0,330 artikel/tahun/peneliti. Dari data tersebut dapat di kemukakan bahwa tidak ada pengaruh antara tingkat pendidikan peneliti dengan jumlah artikel yang dipublikasikan pada jurnal riset akuakultur.

\section{Hubungan antara tingkat pendidikan peneliti dengan jumlah referensi yang digunakan dalam penulisan artikel ilmiah}

Jumlah artikel yang digunakan sebagai referensi dalam penulisan karya tulis ilmiah disajikan pada Gambar 2. Dari 16 orang penulis dengan tingkat pendidikan strata 3 menggunakan referensi sebanyak 500 artikel, sehingga diperoleh rata-rata referensi yang digunakan sebanyak 31,25 artikel dalam satu artikel ilmiah yang ditulis. Untuk tingkat pendidikan strata 2 yaitu dari 26 orang penulis menggunakan referensi sebanyak 470 artikel, sehingga diperoleh rata-rata referensi yang digunakan sebanyak 18,00 artikel.

Sedangkan untuk tingkat pendidikan strata 1 dengan 2 orang penulis, menggunakan referensi sebanyak 89 artikel, sehingga rata-rata penggunaan referensi sebesar 44,5 artikel. Dari hasil analisis dapat dikemukakan bahwa tidak ada pengaruh antara tingkat pendidikan peneliti dengan jumlah referensi yang digunakan dalam penulisan artikel ilmiah. Ismail Suardi Wekke dalam Jahja, A.S. (2017) mempertanyakan "berapa referensi yang patut digunakan dalam sebuah artikel ?". Tidak ada batasan yang baku. Begitu menjawabnya dengan satu kalimat komprehensif. Kondisi yang kedua adalah dimana artikel tersebut akan dipublikasikan?. Jikalau sebuah artikel dipublikasikan dalam jurnal nasional terakreditasi, maka artikel harus menggunakan referensi dengan wawasan internasional.

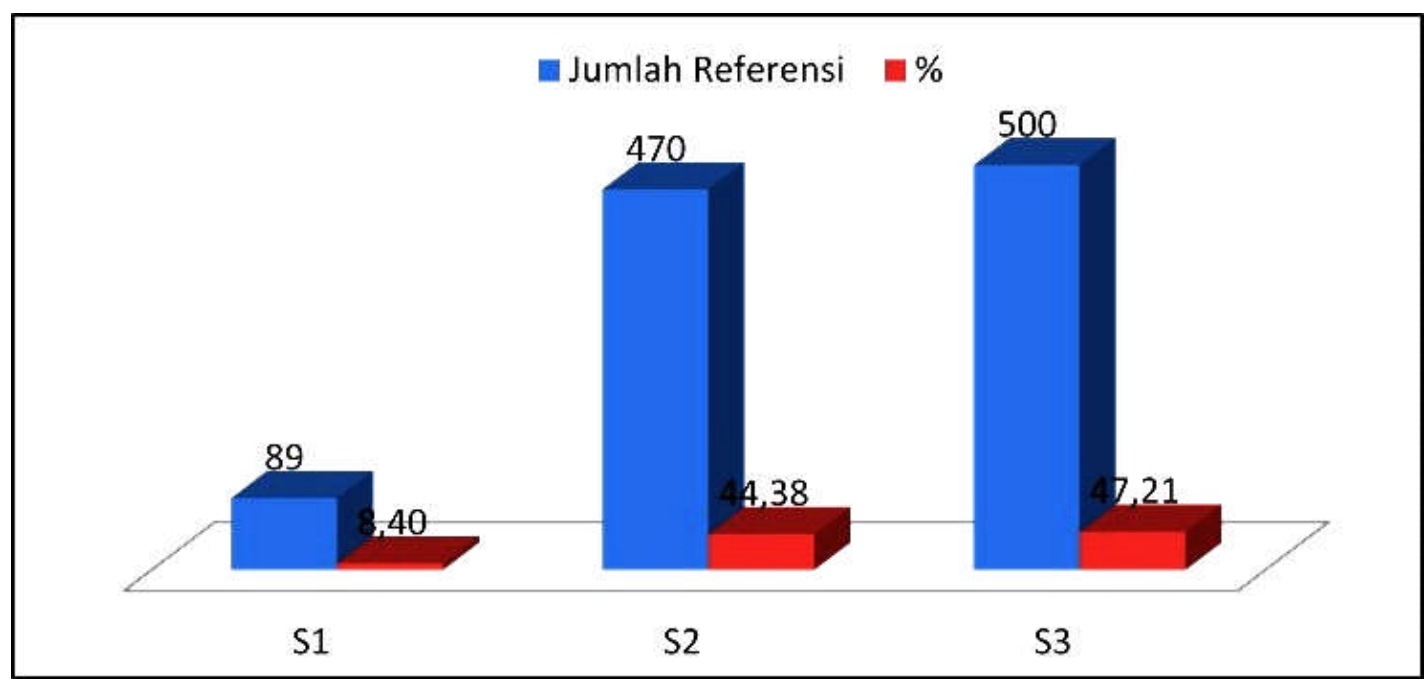

Gambar 2. Hubungan antara tingkat pendidikan dengan Jumlah referensi yang digunakan dalam penulisan artikel ilmiah

\section{Hubungan antara tingkat pendidikan peneliti dengan jenis referensi yang digunakan.}

Jenis koleksi yang digunakan sebagai referensi di kelompokkan menjadi 5 jenis seperti pada Gambar 3. Ditemukan sebanyak 1059 judul artikel yang digunakan sebagai referensi dari 32 artikel yang dikaji.
Dari kelima jenis koleksi yang digunakan sebagai referensi, buku/Monograf menduduki peringkat pertama yaitu sebanyak 470 artikel, majalah/jurnal menduduki peringkat ke dua yaitu sebanyak 460 artikel, menyusul prosiding sebanyak 59 artikel, lainnya sebanyak 47 artikel, dan peringkat terakhir adalah skrips/tesis sebanyak 23 artikel. 


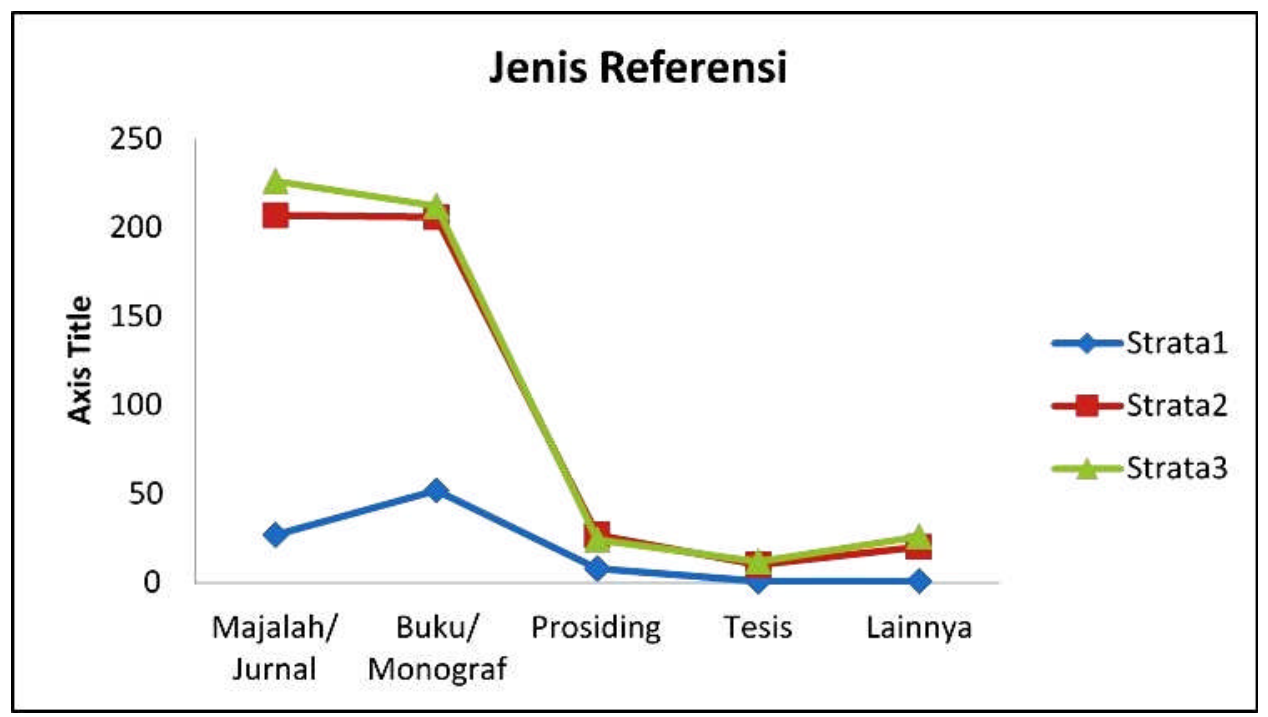

Gambar 3. Hubungan antara Tingkat Pendidikan Peneliti dengan Penggunaan Jenis Referensi

Dari analisis tersebut diperoleh hasil bahwa peneliti dengan tingkat pendidikan strata 3 dan strata 2 lebih cenderung memilih majalah/jurnal sebagai bahan referensi utama. Sedangkan peneliti dengan tingkat pendidikan strata 1 lebih cenderung menggunakan buku/monograf sebagai bahan referensi utama. Skripsi/tesis/disertasi merupakan jenis koleksi yang paling sedikit digunakan oleh peneliti sebagai bahan referensi. Meskipun secara keseluruhan persentase penggunaan buku/monograf lebih tinggi digunakan sebagai bahan referensi dalam penulisan artikel ilmiah oleh penulis.

Romi Satria Wahono (2013), mengemukkan bahwa studi literatur dalam proses penelitian adalah wajib hukumnya, karena dari sana penelitian mulai bergerak. Dia mengemukakan juga bahwa dalam penelitian ilmiah, rujukan utama adalah jurnal ilmiah (scientific journal), baru setelah itu bisa mengambil dari proceedings conference, scientific report, buku dan terbitan lain. Ketinggian derajat keilmiahan sebuah tulisan ilmiah biasanya ditentukan dengan impact factor. Impact factor adalah nilai yang ditentukan dari jumlah rujukan (citation) ke paper-paper di jurnal ilmiah tersebut.

\section{Hubungan antara Tingkat Pendidikan Peneliti dengan Usia Referensi yang digunakan}

Pengguanaan referensi masih sangat bervariasi mulai artikel yang terbit 1 tahun hingga artikel yang diterbitkan lebih dari 60 tahun (Gambar 4). Pada gambar tersebut terlihat bahwa peringkat paling tinggi dalam pengguanaan referensi yaitu artikel usia $1 \mathrm{~s} / \mathrm{d}$ 10 tahun yaitu sebanyak $35,98 \%$. Menyusul penggunaan referensi artikel berusia $11 \mathrm{~s} / \mathrm{d} 20$ tahun yaitu sebanyak $34,94 \%$, usia $21 \mathrm{~s} / \mathrm{d} 30$ tahun sebanyak $19,64 \%$. Sedangkan penggunaan artikel berusia $31 \mathrm{~s} / \mathrm{d} 40$ tahun sebanyak 5,95\%, usia $41 \mathrm{~s} /$ d 50 tahun sebanyak $2,83 \%$ dan masih ada beberapa yang menggunakan referensi koleksi yang sudah terbit 60 tahun keatas yaitu sebanyak $0,66 \%$. Menurut Sulistiyo-Basuki (1992) bahwa kemutakhiran suatu informasi adalah relatif. Pada Gambar 5 lebih rinci disajikan hubungan antara jenjang jabatan fungsional peneliti dengan usia literatur yang dirujuk. Pada gambar tersebut menunjukkan bahwa tingkat pendidikan strata3 lebih cenderung menggunakan referensi yang berusia $1 \mathrm{~s} / \mathrm{d} 10$ tahun (195 artikel). Sedangkan peneliti dengan tingkat pendidikan S2 dan S1 lebih cenderung menggunakan referensi yang berusia $11 \mathrm{~s} / \mathrm{d} 20$ tahun (masing-masing 172 dan 30 artikel). 


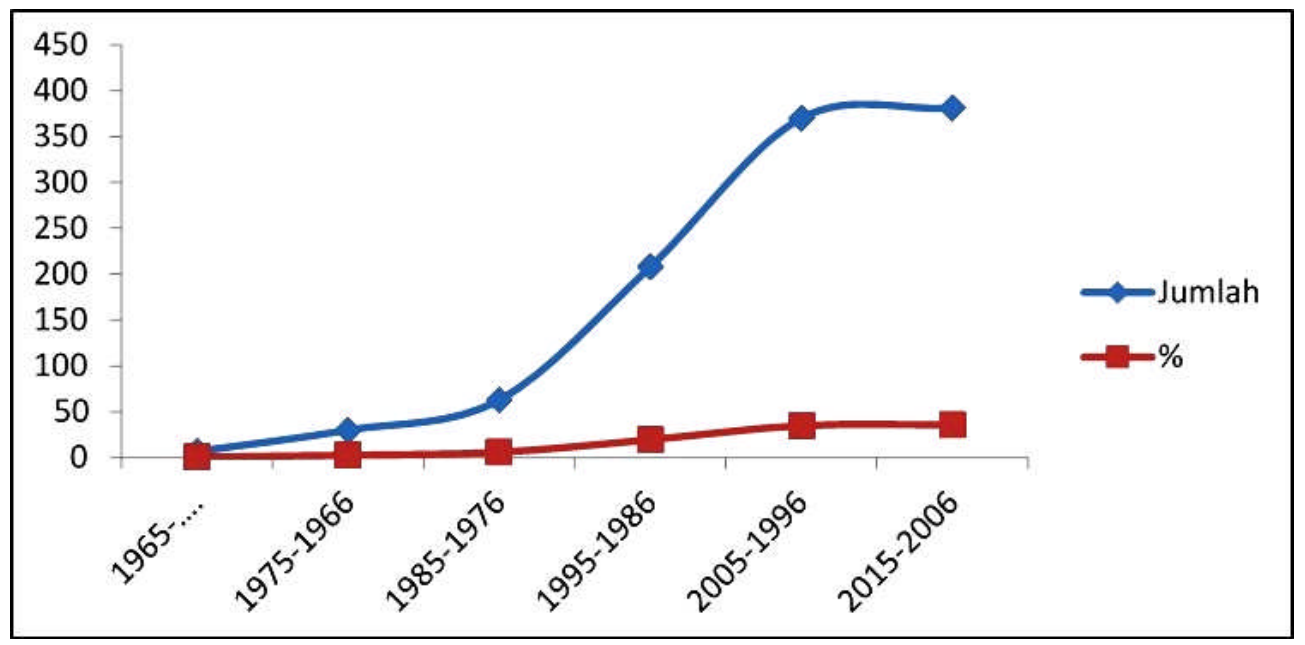

Gambar 4. Penggunaan referensi dalam penulisan karya ilmiah.

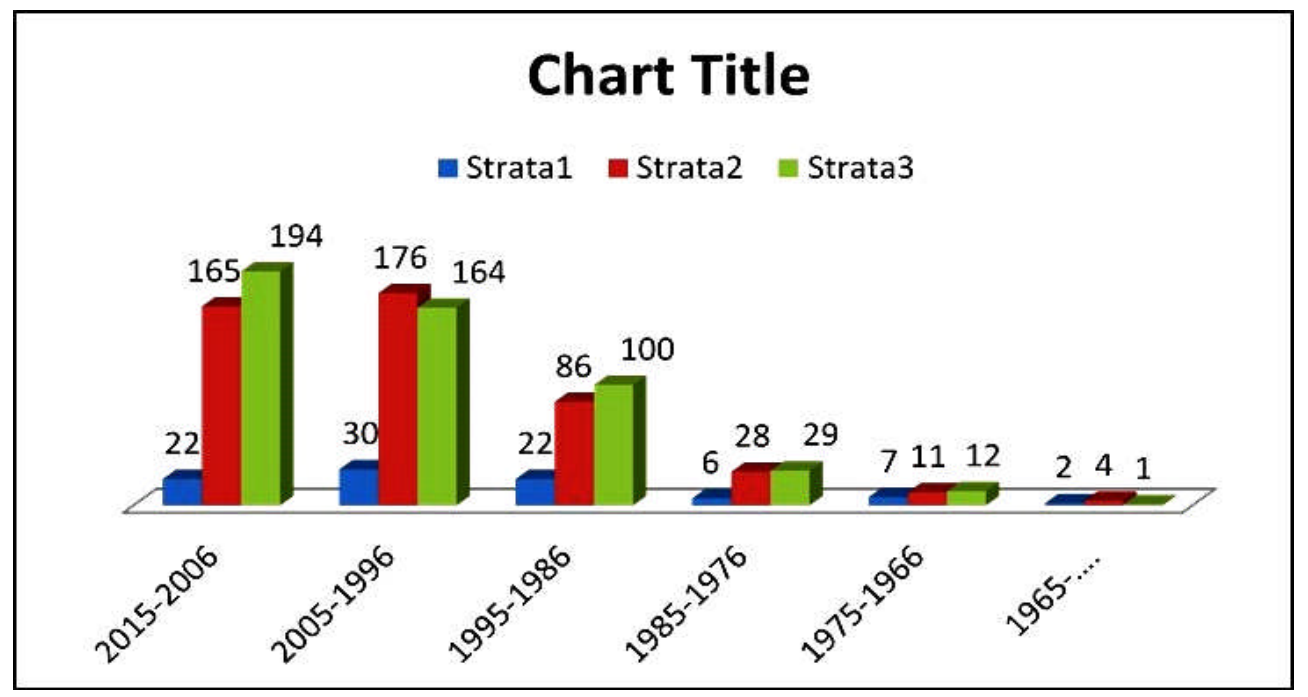

Gambar 5. Hubungan antara Jenjang Jabatan Fungsional Peneliti dengan Usia Literatur yang Dirujuk.

Dalam ilmu bibliometrika, kemutakhiran atau keusangan literature dikenal dengan istilah paro hidup (half-life) literature, yang artinya bahwa separuh dari literatur yang ada dalam bidang tertentu berusia $n$ tahun. Misalnya paroh hidup literature bidang fisika adalah 5 tahun, maka literature yang berusia 6 tahun dianggap sudah usang. Paruh hidup literature dipengaruhi oleh banyaknya literature yang tersedia.

\section{KESIMPULAN}

Dari pembahasan diatas dapat disimpulkan bahwa:

1. Tidak terdapat pengaruh antara tingkat pendidikan terhadap jumlah karya ilmiah yang dipublikasikan melalui jurnal riset akuakultur.

2. Tidak terdapat pengaruh antara tingkat pendidikan terhadap jumlah referensi yang digunakan dalam penulisan karya ilmiah.

3. Tingkat pendidikan strata 3 dan strata 2 lebih cenderung menggunakan majalah/jurnal ilmiah sebagai bahan referensi utama. Sedangkan peneliti dengan tingkat pendidikan strata 1 lebih cenderung menggunakan buku/monograf sebagai bahan referensi utama.

4. Tingkat pendidikan strata3 lebih banyak menggunakan referensi yang berusia $1 \mathrm{~s} / \mathrm{d} 10$ tahun. Sedangkan tingkat pendidikan S2 dan S1 lebih cenderung menggunakan referensi yang berusia $11 \mathrm{~s} / \mathrm{d} 20$ tahun.

\section{DAFTAR PUSTAKA}

Asmana, A. 2019. Pengertian Referensi (Rujukan), Tujuan, Sumber, Dan Cara Penulisan Referensi (Rujukan). Diakses Januari 2020 dari https:// legalstudies71. blogspot.com/2019/12/pengertianreferensi-rujukan-tujuan.html.

Halsey, MJ. dalam Taylor, D. McD. 2002. The appropriate use of references in a scientific research 
paper. Emergency Medicine 14, 2002. Hal. 166170.

Huda, F.A. 2017. Pengertian dan defenisi kajian pustaka. Diakses pada September 2019 dari https://fatkhan.web.id/pengertian-dan-definisikajian-pustaka.

Jahja, A. S. (2017). Refernsi atau daftar pustaka. Diakses pada Oktober 2019. Dari https:// dosen.perbanas.id/referensi-atau-daftar-pustaka.
Martyn, S. 2009. In Text Citation. Retrieved Oct 07, 2018 from Explorable.com.: https:// explorable.com/in-text-citation.

Wahono, R. Satria. 2007. Literatur Penelitian dan Jurnal IImiah Gratis. Diakses pada Agustus 2019 dari https://romisatriawahono.net/2007/10/07/ literatur-penelitian-dan-jurnal-ilmiah-gratis. 